\title{
Penambahan Level Ekstrak Wortel (Daucus carota) pada Pengencer Andromed Dalam Mempertahankan Kualitas Spermatozoa Sapi Bali pada Suhu $5{ }^{\circ} \mathrm{C}$
}

\section{Addition of Carrot (Daucus carota) Ekstract Level to Andromed Diluent in Maintaining the Quality of Bali Cattle Spermatozoa at $5{ }^{\circ} \mathrm{C}$}

\author{
Yuni Mariani", Alimuddin \\ Fakultas Peternakan, Universitas NahdlatulWathanMataram, \\ Jl. Kaktus No. 1-3 (0370) 641275 Mataram \\ *corresponding author, email: mariani.yuni25@gmail.com
}

Manuscript received: 26-10-2020. Accepted: 22-12-2020

\begin{abstract}
ABSTRAK
Bahan pengencer yang baik harus mempunyai kemampuan dalam memperkecil tingkat penurunan kualitas spermatozoa, dengan memilih pengencer yang tepat dan mampu mempertahankan kualitas spermatozoa. Penambahan antioksidan dipercaya mampu mempertahankan hidup spermatozoa lebih lama yaitu salah satunya penambahan ekstrak wortel. Tujuan penelitian ini adalah mempertahankan kualitas spermatozoa sapi bali yang disimpan pada suhu $5{ }^{\circ} \mathrm{C}$ dengan memanfaatkan ekstrak wortel karena mengandung antioksidan. Penelitian ini menggunakan Rancangan Acak Lengkap terdiri dari 5 perlakuan dan 5 kali ulangan yaitu $\mathrm{P} 0=$ semen + andromed, $\mathrm{P} 1=$ semen + andromed $+5 \%$ ekstrak wortel, $\mathrm{P} 2=$ semen + andromed $+10 \%$ ekstrak wortel, $\mathrm{P} 3=$ semen + andromed $+15 \%$ ekstrak wortel, P4 $=$ semen + andromed $+20 \%$ ekstrak wortel. Variabel yang diukur adalah kualitas spermatozoa secara mikroskopis yaitu motilitas dan viabilitas spermatozoa. Hasil penelitian menunjukkan bahwa penambahan level ekstrak wortel pada pengencer andromed dalam mempertahankan motilitas spermatozoa pada suhu $5{ }^{\circ} \mathrm{C}$ menunjukkan tidak signifikan $(\mathrm{P}>0.05)$ artinya setiap perlakuan memiliki pengaruh yang sama dalam mempertahankan motilitas spermatozoa. Persentase motilitas pada semua perlakuan layak diaplikasikan pada program IB karena masih menunjukkan nilai lebih dari $40 \%$.
\end{abstract}

Kata kunci:antioksidan; perlakuan; ekstrak; kualitas; sapi bali

\footnotetext{
ABSTRACT

A good diluents must have the ability to reduce the rate of decline in the quality of spermatozoa, by choosing the right diluents that is able to maintain the quality of spermatozoa. The addition of antioxidants is believed to be able to maintain spermatozoa life longer, one of which is the addition of carrot extract. The purpose of this study was to maintain the quality of Bali cattle spermatozoa stored at $5{ }^{\circ} \mathrm{C}$ by utilizing the quality of bali cattle spermatozoa because they contain antioxidants. This study used a completely randomized design (CRD) consisting of 5 treatments and 5 replications, namely: P0
} 
$=$ cement + andromed, $\mathrm{P} 1=$ cement + andromed $+5 \%$ carrot extract, $\mathrm{P} 2=$ cement + andromed +10 $\%$ carrot extract, $\mathrm{P} 3=$ cement + andromed $+15 \%$ carrot extract, $\mathrm{P} 4=$ cement + andromed $+20 \%$ carrot extract. The variables measured were the quality of the spermatozoa microscopically, namely the motility and viability of the spermatozoa. The result showed that the increase in the level of carrot extract in andromed diluent in maintaining spermatozoa motility at $5{ }^{\circ} \mathrm{C}$ was not significant $(\mathrm{P}>0,05)$, meaning that each treatment had the same effect in maintaining spermatozoa motility. The percentage of motility in all treatments is feasible to be applied to the IB program because is still shows a value of more than $40 \%$.

Key words:antioxidants; extract; treatment; quality; bali cattle

\section{PENDAHULUAN}

Sapi Bali merupakan salah satu jenis sapi lokal Indonesia yang berasal dari Bali yang sekarang telah menyebar hampir ke seluruh penjuru Indonesia bahkan sampai luar negeri seperti Malaysia, Filipina, dan Australia. Sapi Bali memiliki kemampuan reproduksi yang baik dan daya adaptasi yang sangat baik pada pemeliharaan intensif maupun ekstensif di padang penggembalaan. Salah satu cara untuk meningkatkan populasi sapi bali adalah dengan melestarikan mutu genetic sapi bali dengan melakukan Inseminasi Buatan (IB).

IB merupakan salah satu teknologi reproduksi yang dilakukan dengan mendesposisikan semen ke dalam alat kelamin ternak betina dengan menggunakan alat inseminasi. Teknologi IB yang digunakan unntuk program peningkatan mutu genetik terutama pada ruminansia besar (sapid an kerbau) merupakan teknologi unggulan yang masih akan digunakan dalam upaya peningkatan produktivitasnya. Dijelaskan lebih lanjut bahwa, tingkat ke berhasilan IB sangat dipengaruhi oleh empat factor yang saling berhubungan yaitu kualitas semen, pemilihan sapi betina akseptor, akurasi deteksi birahi dan keterampilan inseminator (Kartasudjana, 2001).

Pengencer andromed merupakan pengencer siap pakai yang tidak mengandung kuning telur. Pengencer semen komersial ini tidak terkontaminasi mikroorganisme yang berasal dari kuning telur serta mudah penanganan dan waktu penyimpanan. Pengencer andromed merupakan suatu medium tanpa kuning telur untuk semen beku dan cair yang mempunyai angka fertilitas tinggi. Pengencer andromed mengandung protein, karbohidrat (fruktosa, glukosa, manosa, dan maltotriosa), mineral (natrium, kalsium, kalium, magenesium, klorida, fosfor, dan mangan), asam sitrat, gliserol, lemak, lesitin, dan glyceryl phosphoryl choline (GPC) (Feradis, 2010).

Wortel (Daucus carota) merupakan salah satu jenis sayuran yang telah dikenal luas oleh masyarkat. Wortel kaya akan kandungan antioksidan, teristimewa $\beta$-karoten yang dapat larut dalam lemak atau minyak. Antioksidan merupakan suatu zat yang dapat menjaga struktur dan fungsi spermatozoa dari kerusakan selama penyimpanan, selain itu juga dapat menangkal dan mencegah reaksi yang memicu kerusakan sel dalam tubuh spermatozoa (Suyadi dkk, 2012).

Bahan pengencer dari ekstrak wortel belum banyak diteliti. Antioksidan yang terdapat dalam wortel ini diduga memliki daya perlindungan yang baik bagi spermatozoa. Hal ini yang melatarbelakangi perlu dilakukan penelitian tentang pengaruh level ekstrak wortel (Daucus carota) pada pengencer andromed dalam mempertahankan kualitas 
spermatozoa sapi bali yang disimpan pada pada suhu suhu ${ }^{0} \mathrm{C}$ pada pengencer andromed yang ditambahkan ekstrak wortel dengan level yang berbeda. Hasil penelitian ini diharapkan secara ekonomis akan mampu meningkatkan pendapatan peternak dan dapat digunakan dalam program peningkatan efisiensi reproduksi ternak yang selanjutnya berguna bagi perkembangan ilmu dan teknologi ditingkat perguruan tinggi.

\section{Materi Penelitian}

\section{BAHAN DAN METODE}

Penelitian ini menggunakan semen sapi bali yang ditampung dari 5 ekor yang berumur 3-8 tahun. Alat yang digunakan dalam penelitian ini adalah vagina buatan, beaker glass, obyek glass, thermometer, timbangan analitik, $\mathrm{pH}$ meter, spectrophotometer, mikroskop, kulkas, dan alat sentrifuge. Bahan yang digunakan adalah ekstrak wortel, andromed, aquades, eosin negrosin dan $\mathrm{NaCl}$.

\section{Metode Penelitian}

Metode yang digunakan dalam penelitian ini adalah eksperimental laboratorik dengan rancangan penelitian yang digunakan adalah Rancangan Acak Lengkap (RAL) dengan 5 perlakuan dan 5 kali ulangan yaitu: $\mathrm{P} 0=$ semen + pengencer andromed; $\mathrm{P} 1=$ semen +pengencer andromed + ekstrak wortel $5 \% ; \mathrm{P} 2=$ semen + pengencer andromed $+10 \% ; \mathrm{P} 3=$ semen + pengencer andromed + akstrak wortel $15 \%$; dan $\mathrm{P} 4=$ semen + pengenceran andromed + ekstrak wortel $20 \%$.

\section{Pembuatan Eksrak Wortel}

Wortel yang sudah dicuci bersih, kemudian dikukus pada suhu $90{ }^{0} \mathrm{C}$ selama 10 menit. Wortel yang sudah dikukus, ditimbang sebanyak 100 gram. 100 gram wortel dan aquades di blender hingga halus. Setelah itu wortel + aquades (1:1) yang sudah homogen dimasukkan dalam tabung reaksi dan disentrifugasi dengan kecepatan $300 \mathrm{rpm}$ selama 15 menit. Supernata (cairan yang being) diambil menggunakan mikropipet dan disimpan dalam tabung reaksi pada suhu $5{ }^{\circ} \mathrm{C}$ untuk menghindari terjadinya kerusakan pada ekstrak wortel. Ekstrak wortel siap digunakan sebagai bahan pengencer.

\section{Penampungan Semen}

Penampunagan semen dilakukan pada pagi hari menggunakan vagina buatan. Suhu dalam vagina buatan mencapai $40-45{ }^{\circ} \mathrm{C}$ dan dan vagina buatan disimpan dalam incubator $45-50{ }^{0} \mathrm{C}$.

\section{Pemeriksaan secara Makroskopis dan Mikroskopis}

Semen yang digunakan dalam penelitian dievaluasi secara makroskipis dan mikroskopis. Pemeriksaan makroskopis meliputi: volume, bau, warna, $\mathrm{pH}$, dan konsistensi. Pemeriksaan secara mikroskopis meliputi konsentrasi, motilitas, dan gerak massa. 


\section{Penyimpanan Semen}

Setelah diencerkan sampel disimpan dalam tabung reaksi, kemudian disimpan di dalam lemari es dengan suhu ${ }^{0} \mathrm{C}$. Pengukuran daya tahan sperma dilakukan melalui pemeriksaan secara mikroskopis. Pemeriksaan dilakukan setelah disimpan 24 jam, 48 jam dan 72 jam.

\section{Variabel Penelitian}

Variable yang diukur dalam penelitian ini adalah persentase motilitas dan persentase viabilitas spermatozoa. Persentase motilitas dihitung dengan meneteskan semen pada objek glass dan ditutup dengan cover glass, kemudian diamati di bawah mikroskop pada pembesaran 400x.

$$
\text { Motilitas (\%) }=\frac{\text { Jumlah spermatozoa Motil }}{\text { Jumlah spermatozoa yang dihitung }} \times 100 \%
$$

Viabilitas diketahui melalui pewarnaan diferensial (dibuat preparat apus). Preparat ulas dibuat setelah beberapa detik sampai satu menit dana segera dikeringkan dekat nyala api.

$$
\text { Viabilitas }(\%)=\frac{\text { Jumlah spermatozoa yang hidup }}{\text { Jumlah spermatozoa yang dihitung }} \times 100 \%
$$

\section{Analisa Data}

Data yang diperleh dianalisis menggunakan analisis varian's (ANOVA) untuk mengetahui pengaruh perlakuan yang diuji dan dilanjutkan dengan uji BNJ.

\section{HASIL DAN PEMBAHASAN}

\section{Kualitas Semen Segar Sapi Bali}

Pemeriksaan semen segar ini bertujuan untuk mengetahui layak atau tidaknya semen tersebut diproses lebih lanjut, baik pemeriksaan secara secara makroskopis maupun mikroskopis. Pemeriksaan secara makroskopis merupakan suatu pemeriksaan tanpa menggunakan alat bantu, dimana pemeriksaan makroskopis ini meliputi volume, bau, warna, dan kekentalan, sedangkan pemeriksaan mikroskopis merupakan pemeriksaan menggunakan alat bantu berupa mikroskop. Toelihere (1993) menyatakan bahwa segera sesudah penampungan, semen harus diperlakukan hati-hati untuk mencegah cold shock atau pemanasan tinggi, kontaminasi dengan air, urine dan bahan-bahan kimia, pengocokan atau goncangan yang berlebih-lebihan atau exposure ke udara atau sinar matahari yang langsung. Hasil evaluasi semen segar sapi bali dalam penelitian ini disajikan pada Tabel 1. Aroma semen yang dihasilkan pada penelitian ini yaitu aroma khas semen. Aroma tersebut menunjukkan semen tersebut dalam keadaan normal dan tidak terdapat kontaminasi. Semen dengan keadaan normal umumnya mempunyai aroma yang khas disertai dengan aroma dari khas hewan tersebut. Sesuai dengan pendapat Kartasudjana (2001) yang menyebutkan bahwa semen normal umumnya memiliki aroma khas dari hewan tersebut, apabila terdapat aroma busuk menunjukkan semen bercampur dengan nanah. Warna semen yang dihasilkan adalah putih susu. Warna putih susu pada semen sapi menunjukkan bahwa semen tersebut normal. 
Feradis (2010) menambahkan bahwa semen sapi normal berwarna putih susu atau krem an keruh. Derajat kekeruhannya tergantung pada konsentrasi spermatozoa. Warna semen juga berkaitan dengan konsentrasinya. Suyadi dkk. (2012) menjelaskan bahwa warna, konsistensi dan konsentrasi spermatozoa saling berkaitan satu dengan yang lain, artinya jika semen semakin encer maka konsentrasi spermatozoa semakin rendah dan warnanya semakin pucat. Selain itu, Warna dipengaruhi oleh pigmenriboflavin yang dibawa oleh satu gen autosomal resesif, yang dihasilkan oleh kelenjar accessories (Hafez \& Hafez, 2000).

Tabel 1. Rataan Hasil Evaluasi Semen Segar Sapi Bali

\begin{tabular}{cc}
\hline Parameter & Rataan nilai \\
\hline Volume $(\mathrm{ml})$ & 6,05 \\
Bau & Khas semen \\
Warna & Putih susu \\
Kekentalan & Kental \\
Ph & 6,60 \\
Gerakan Massa & ++ \\
Motilitas (\%) & 75 \\
Konsentrasi & 1613 \\
\hline
\end{tabular}

Konsistensi atau kekentalan semen yang diperoleh adalah kental. Konsistensi, konsentrasi dan warna semen mempunyai hubungan yang berbanding lurus dengan jumlah spermatozoa yang terkandung dalam semen tersebut. $\mathrm{pH}$ semen yang diperoleh pada penelitian ini sebesar 6,60. pH semen sapi bali dalam penelitian ini tergolong pada kisaran normal. Sesuai dengan pernyataan Garner dan Hafez (2008) menyatakan, bahwa pH semen segar pada sapi berkisar antara 6,4-7,8. Variasi nilai $\mathrm{pH}$ dapat dipengaruhi oleh beberapa factor diantaranya adalah adanya aktifitas spermatozoa dalam menguraikan fruktosa sehingga $\mathrm{pH}$ menjadi turun, kontaminasi dengan kuman sehingga $\mathrm{pH}$ naik dan adanya perbedaan cara mengoleksi semen.

Gerak massa spermatozoa mempunyai kecenderungan untuk bergerak bersama-sama ke satu arah membentuk gelombang-gelombang yang tebal dan tipis, bergerak cepat atau lambat, tergantung konsentrasi spermatozoa hidup. Gerak massa yang diperoleh dalam penelitian ini adalah positif dua (++). Motilitas semen sapi bali dalam penelitian ini tergolong cukup baik, seperti pendapat Drajat (2002) bahwa, semen yang baik mempunyai motilitas individu berkisar antara $70-80 \%$.

Penilaian konsentrasi spermatozoa sapi bali sangan penting dilakukan, karena digunakan sebagai criteria penentu kualitas semen yang dijadikan untuk menentukan tingkat pengenceran. Konsentrasi yang didapat pada penelitian ini adalah 1.613 x $10^{9} \mathrm{ml}$.

Kualitas Semen Setelah Penyimpanan

Motilitas. Motilitas merupakan salah satu penilaian kualitas spermatozoa untuk Innseminasi Buatan. Kualitas semen dapat menunjukkan kemampuan spermatozoa dalam melakukan pergerakan, daya tahan hidup sebagai ukuran kesanggupan spermatozoa untuk membuahi ovum. Rata-rata motilitas spermatozoa sapi bali setelah ditambahkan pengencer dan disimpan pada suhu ${ }^{0} \mathrm{C}$ disajikan pada Tabel 2. 
Tabel 2. Rata-rata motilitas spermatozoa sapi Bali setelah pengenceran dan penyimpan pada suhu ${ }^{0} \mathrm{C}$

\begin{tabular}{cccc}
\hline \multirow{2}{*}{ Perlakuaan } & \multicolumn{3}{c}{ Penyimpanan pada Suhu $5{ }^{\circ} \mathrm{C}$} \\
\cline { 2 - 4 } & $24 \mathrm{Jam}$ & $48 \mathrm{Jam}$ & $72 \mathrm{Jam}$ \\
\hline P0 & $65.00^{\mathrm{a}} \pm 5.00$ & $60.67^{\mathrm{a}} \pm 4.04$ & $51.67^{\mathrm{a}} \pm 2.89$ \\
P1 & $61.67^{\mathrm{a}} \pm 3.51$ & $58.33^{\mathrm{a}} \pm 2.89$ & $50.33^{\mathrm{a}} \pm 2.52$ \\
P2 & $59.00^{\mathrm{a}} \pm 1.73$ & $54.33^{\mathrm{a}} \pm 4.04$ & $48.00^{\mathrm{a}} \pm 2.65$ \\
P3 & $55.67^{\mathrm{a}} \pm 4.93$ & $52.67^{\mathrm{a}} \pm 2.52$ & $47.33^{\mathrm{a}} \pm 2.08$ \\
P4 & $54.00^{\mathrm{a}} \pm 3.61$ & $49.00^{\mathrm{a}} \pm 1.00$ & $43.33^{\mathrm{a}} \pm 2.89$ \\
\hline
\end{tabular}

Keterangan: Superskrip yang sama pada baris dan kolom yang sama menunjukkan tidak berbeda nyata $(\mathrm{P}>0.05)$

Berdasarkan Tabel 2. Bahwa penambahan level ekstrak wortel pada pengencer andromed dalam mempertahankan motilitas spermatozoa pada suhu ${ }^{0} \mathrm{C}$ menunjukkan tidak signifikan $(\mathrm{P}>0.05)$ artinya setiap perlakuan memiliki pengaruh yang sama dalam mempertahankan motilitas spermatozoa. Hasil penelitian ini sesuai dengan penelitian yang pernah dilakukan oleh Yendraliza et al.(2008) yang menambahkan sari wortel dalam pengencer andromed pada semen sapi bali dan dibekukan menunjjukkan tidak ada perbedaan nyata dalam mempertahankan motilitas spermatozoa. Hasil penelitian ini lebih tinggi nilai motilitasnya dibandingkan dengan hasil penelitian Parera et al.(2009) yang menggunakan sari wortel denga tris pada spermatozoa sapi bali asal cauda epididymis $(27.50 \%)$. Perbedaan ini mungkin disebabkan oleh jenis pengencer yang berbeda, umur, jenis ternak yang digunakan, pakan, pakan, system pemeliharaan dan model koleksi semen.

Persentase motilitas pada semua perlakuan layak diaplikasikan karena masih menunjukkannilai lebih dari $40 \%$. Menurut BSN (2007) bahwa syarat spermatozoa sapi dikatakan hidup dan bergerak maju (motil) setelah pengenceran adalah 55\% dan setelah thawing minimal $\geq 40 \%$.

Viabilitas. Viabilitas merupakan jumlah spermatozoa yang hidup. Rata-rata viabilitas spermatozoa sapi Bali setelah ditambahkan pengencer dan disimpan pada suhu $5{ }^{\circ} \mathrm{C}$ disajikan pada Tabel 3.

Tabel 3. Rata- rata viabilitas spermatozoa sapi Bali setelah pengenceran dan penyimpanan pada suhu $5{ }^{\circ} \mathrm{C}$

\begin{tabular}{cccc}
\hline \multirow{2}{*}{ Perlakuaan } & \multicolumn{3}{c}{ Penyimpanan pada Suhu $5{ }^{\circ} \mathrm{C}$} \\
\cline { 2 - 4 } & $24 \mathrm{Jam}$ & $48 \mathrm{Jam}$ & $72 \mathrm{Jam}$ \\
\hline P0 & $75.20^{\mathrm{a}} \pm 6.72$ & $71.60^{\mathrm{a}} \pm 5.27$ & $60.00^{\mathrm{a}} \pm 6.86$ \\
P1 & $72.20^{\mathrm{a}} \pm 9.31$ & $65.60^{\mathrm{a}} \pm 6.02$ & $59.40^{\mathrm{a}} \pm 7.67$ \\
P2 & $69.00^{\mathrm{a}} \pm 7.28$ & $61.00^{\mathrm{a}} \pm 5.52$ & $51.80^{\mathrm{a}} \pm 3.19$ \\
P3 & $71.40^{\mathrm{a}} \pm 14.52$ & $65.80^{\mathrm{a}} \pm 12.62$ & $54.60^{\mathrm{a}} \pm 7.47$ \\
P4 & $76.00^{\mathrm{a}} \pm 4.18$ & $69.80^{\mathrm{a}} \pm 10.83$ & $56.40^{\mathrm{a}} \pm 6.39$ \\
\hline
\end{tabular}

Keterangan: Superkrip yang sama pada baris dan kolom yang sama menunjukkan tidak adanya perbedaan yang nyata $(\mathrm{P}>0.05)$.

Penambahan ekstrak wortel terhadap nilai viabilitas spermatozoa pada Tabel 3. Menunjukkan pengaruh yang sama $(\mathrm{P}>0.05)$. Nilai viabilitas yang diperoleh dalam penelitian 
ini lebih rendah dibandingakan dengan penelitian yang telah dilakukan oleh Yendraliza et al. (2018), bahwa niali viabilitas yang diperoleh setelah thawing mencapai $85 \%$. Hal ini disebabkan karena proses pembekuan menyebabkan metabolism akan lebih berkurang, sehingga akan mengurangi penumpuka asam laktat yang menyebabkan kematian spermatozoa (Gordon, 2017).

\section{KESIMPULAN}

Berdasarkan hasil penelitian yang diperoleh dapat disimpulkan bahwa persentase motilitas pada semua perlakuan layak diaplikasikan pada program IB karena masih menunjukkan nilai lebih dari $40 \%$ dan masih menunjukkan nilai viabilitas yang baik yaitu $56.40 \%$.

\section{Ucapan Terimakasih}

Terimaksih kami ucapkan kepada kemenritekdikti yang telah memeberikan pendanaan dalam penelitian ini melalui program Hibah Penelitian Dosen Pemula, Pelaksanaan tahun 2020.

\section{DAFTAR PUSTAKA}

Badan Standarisasi Nasinonal. 2007. Semen Beku Sapi. BSN Drajat, A.S.2002. Inseminasi Buatan pada Rusa Indonesia. Prosiding Seminar Nasional Peningkatan Pendapatan Petani Melalui Penerapan Teknologi Tepat Guna. 156-162

Feradis. 2010. Bioteknologi Reproduksi pada Ternak. Alfabeta, Bandung

Garner, D. L. and E. S. E. Hafez. 2008. Spermatozoa and Seminal Plasma in Reproduction in Farm Animals. 7 th Edition. Edited by Hafez, E.S.E. Co. Director. Reproductive Health Kiawah Island. South Carolina. USA. 7 : 96-109.

Garner, D.L. and E. S. E. Hafez. 2016. Spermatozoa and Seminal Plasma. In : Reproduction in Farm Animals. Baltimore, Maryland, USA : Lippicott Williams and Wilkins. Pp. 96-109.

Gordon, I. 2017. Reproductive technologies in farm animals 2nd Edition. University College Dublin. Ireland.

Hafez, B. \& E. S. Hafez. 2000. Reproduction in Farm Animals. Baltimore, Lippincott Williams \& Wilkins. Maryland, USA.

Kartasudjana, R. 2001. Teknik Inseminasi Pada Ternak. Departemen Pendidikan Nasional. Direktorat Pendidikan Menengah Kejuruan Jakarta.

Parera, F. Z. Prihatiny, D.F. Souhoka, dan M. Rizal. 2009. Pemanfaatan Sari Wortel Sebagai Pengencer Alternative Spermatozoa Epididimis Sapi Bali. J. Indonesia Tropical Animal Agriculture, 34 (1) : 50-5

Suyadi, A. Rachmawati dan N. Iswanto. 2012. Pengaruh $\alpha$ - Tocopherol yang Berbeda dalam Pengencer Aminomethane-Kuning Telur Terhadap Kualitas Semen Kambing Boer yang disimpan pada suhu $5{ }^{0} \mathrm{C}$. Jurnal Ilmu-ilmu Peternakan. 22(3) : 1-8 
Toelihere, M. R. 1993. Inseminasi Buatan pada Ternak. Angkasa Bandung. GWSalisburyN.I.Vandermark.R.Djanuar.1995.Fisikologi Reproduksi dan Inseminasi Buatan pada Ternak.

Yendraliza, M. Musyrifin, Elviriadi, Zumarni, M. Rodiallah. 2018. Viabilitas Sapi Bali menggunakan Pengencer Andrmed dengan penambahan Konsentrasi Sari Wortel yang berbeda. Jurnal Ilmu dan Teknologi Peternakan Tropis. 6(2): 239:245. 